\title{
Study of blind thrust faults underlying Tokyo and Osaka urban areas using a combination of high-resolution seismic reflection profiling and continuous coring
}

\author{
Yuichi Sugiyama $\left({ }^{1}\right)$, Kiyohide Mizuno $\left({ }^{2}\right)$, Futoshi Nanayama $\left({ }^{1}\right)$, \\ Toshihiko Sugai $\left({ }^{3}\right)$, Hiroshi Yokota $\left({ }^{4}\right)$, Takashi Hosoya $\left({ }^{5}\right)$, Kenichiro Miura $\left({ }^{6}\right)$, \\ Keiji Takemura $\left({ }^{7}\right)$ and Naoko Kitada $\left({ }^{8}\right)$ \\ $\left(^{1}\right)$ Active Fault Research Center, Geological Survey of Japan, National Institute of Advanced Industrial \\ Science and Technology, Tsukuba, Japan \\ $\left.{ }^{2}\right)$ Active Fault Research Center, Geological Survey of Japan, National Institute of Advanced Industrial \\ Science and Technology, Osaka, Japan \\ $\left(^{3}\right)$ Department of Natural Environmental Studies, University of Tokyo, Japan \\ $\left.{ }^{4}\right)$ Hanshin Consultants Co. Ltd., Osaka, Japan \\ (5) Chuo Kaihatsu Corporation, Tokyo, Japan \\ $\left({ }^{6}\right)$ Kiso-jiban Consultants Co. Ltd., Chiba, Japan \\ $\left(^{7}\right)$ Institute for Geothermal Sciences, Kyoto University, Beppu, Japan \\ $\left({ }^{8}\right)$ Geo-Research Institute, Osaka, Japan
}

\begin{abstract}
We acquired high-resolution seismic reflection profiles and continuously cored boreholes to evaluate active flexures produced by major blind thrust fault systems within two densely populated Neogene-Quaternary sedimentary basins in Japan: the Fukaya Fault System near Tokyo in the Kanto Basin and the Uemachi Fault System in the Osaka Basin. The high-resolution seismic reflection survey made clear the length, geometry and growth history of fault-related folds, or flexures formed above the two blind thrusts. Continuously cored boreholes linked with high-resolution seismic profiles enabled us to estimate the uplift rate as defined by shallow stratigraphic horizons and constrain the age of the most recent growth of the flexures during earthquakes on the Fukaya and Uemachi fault systems. Even with the high quality of the data we collected, it is still not possible to exactly constrain the age of the most recent blind thrust earthquake recorded by flexure of these fault-related folds. Data presented in this paper form the basis for future efforts aimed at mechanical and kinematic models for fault growth to evaluate the activity of blind thrusts underlying urban areas.
\end{abstract}

Key words blind thrust-fault-related fold-flexurehigh-resolution seismic reflection profiling - continuous coring

Mailing address: Dr. Yuichi Sugiyama, Active Fault Research Center, Geological Survey of Japan, National Institute of Advanced Industrial Science and Technology, Higashi 1-1-1, Tsukuba, 305-8567, Japan; e-mail: sugiyama-y@aist.go.jp

\section{Introduction}

In Japan several Neogene-Quaternary sedimentary basins have developed in close association with active faults along their margins. As the basins are composed of Plio-Pleistocene deposits more than one thousand meters thick, some of the active faults do not appear at the surface, but are expressed at the surface as a flex- 
ure or monocline usually one to several hundred meters wide. These flexures are commonly concealed beneath young Holocene deposits and show no geomorphic expression. High-resolution seismic reflection profiling is useful for studying this type of active blind fault with no topographic expression but with a wide subsurface deformation zone.

Continuously cored boreholes coupled with high-resolution seismic reflection profiles are especially useful for obtaining data on fault activity such as uplift rate. We applied this combination of methods to flexures that have grown in response to repeated earthquakes of two major blind thrust fault systems in the densely populated Kanto and Osaka basins, Japan.

\section{Fukaya Fault System in the Kanto Basin}

\subsection{Kanto Basin}

The Kanto Basin is situated where the Pacific and Philippine Sea plates are subducted beneath Eastern Japan respectively from the east and south (fig. 1). The basin is approximately $150 \mathrm{~km}$ wide and $130 \mathrm{~km}$ long in E-W and N-S directions. Greater metropolitan Tokyo with a population of more than 30 million lies within this basin. Neogene-Quaternary deposits are $3000 \mathrm{~m}$ deep in the central and northwestern parts of the Kanto Basin. Active faults are recognized within the basin around its northwest and western peripheries. Geodetic surveys in the past 100 years show that the northwestern part of the basin is subject to compression in ENE-WSW direction and extension in NNW-SSE direction (e.g., Geographical Survey Institute, 2002).

\subsection{Fukaya Fault}

The Fukaya Fault is located in the northwestern part of the Kanto Basin (fig. 2). This NWtrending west-side-up fault is identified by a 12 $\mathrm{km}$ long flexure or monocline, 4 to $14 \mathrm{~m}$ high and about $100 \mathrm{~m}$ wide, extending across Pleistocene terraces. NW-trending east-side-up back thrusts such as the Kushibiki and Hirai faults also exist as flexures on Pleistocene terraces about 5 to $10 \mathrm{~km}$

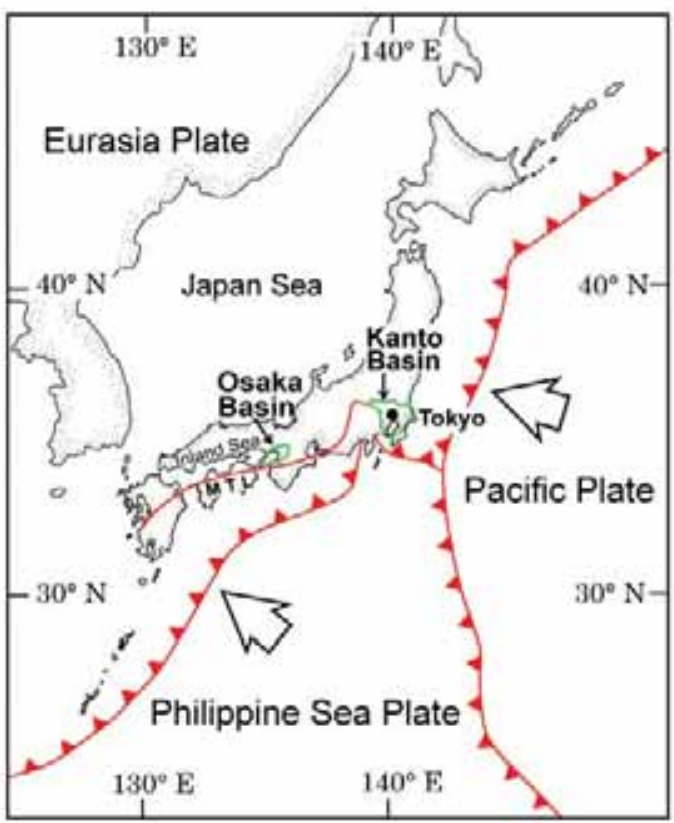

Fig. 1. Simplified tectonic setting of Japan and location of the Kanto and Osaka basins. MTL: Median Tectonic Line. Open arrows show relative convergence direction between Japan and the Pacific and Philippine Sea plates, respectively.

southwest of the Fukaya Fault (fig. 2). The longterm uplift rate is estimated to be $0.3-0.4 \mathrm{~m} / \mathrm{ky}$ for the Fukaya Fault and around $0.1 \mathrm{~m} / \mathrm{ky}$ for the Kushibiki and Hirai faults based on measured displacements and the inferred age of terrace surfaces (Yamazaki, 1984). Although a very shallow earthquake of magnitude 6.9 occurred in 1931 close to the Fukaya Fault, no surface rupture was recognized along the fault zone. The focal mechanism determined by Abe (1974) for the 1931 earthquake is consistent with NE-SW compression and left-lateral strike slip on an $\mathrm{N} 70^{\circ} \mathrm{W}$-trending nearly vertical source fault.

\subsection{High-resolution seismic reflection profiling}

Since the mid 1990's, the National Institute for Earth Science and Disaster Prevention (Ka- 


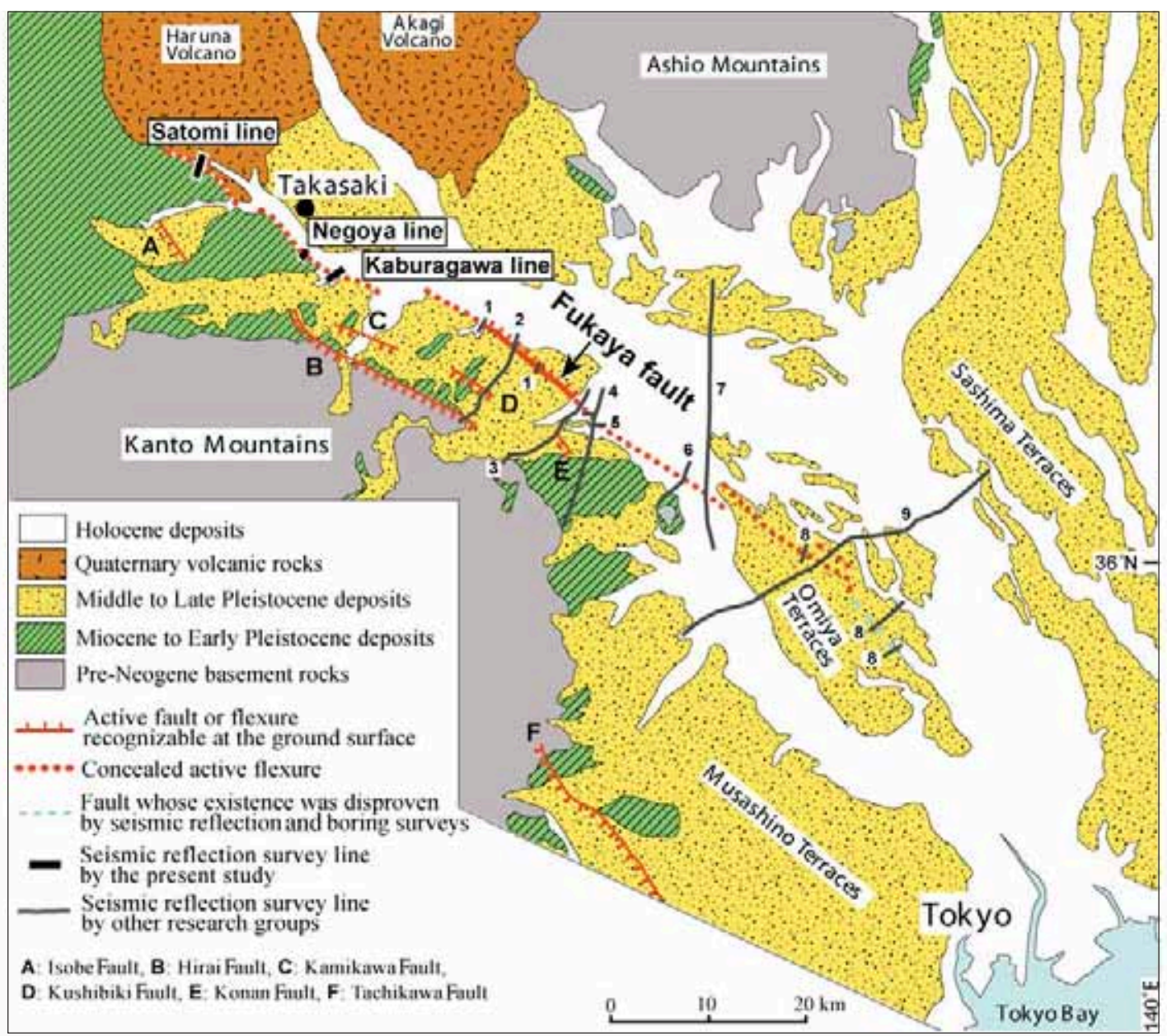

Fig. 2. Simplified geologic map of the central to northwestern part of the Kanto Basin. Simplified from Sugiyama et al. (1997). The basin is bounded by the Kanto and Ashio mountains on the west and north, respectively. Seismic reflection surveys shown by numbered survey lines were conducted by the following authors: 1 - Saitama Prefecture (1999); 2 - Yamaguchi et al. (1996); 3 - Yamaguchi et al. (2000); 4 - Ikawa et al. (1998); 5 - Inazaki et al. (1988); 6 - Yamaguchi et al. (1998); 7 - Kasahara (1996); 8 - Saitama Prefecture (1996); 9 - Kasahara et al. (1993).

sahara et al., 1993; Kasahara, 1996) and the Geological Survey of Japan (Yamaguchi et al., 1996, 1998, 2000) have carried out comprehensive seismic reflection surveys to reveal the subsurface structure of the Kanto Basin (fig. 2). Saitama Prefecture $(1996,1999)$ also undertook acquisition of seismic reflection profiles to evalua- te the Fukaya Fault and its southeastern extension in the Omiya terraces (fig. 2). These studies revealed that the Fukaya Fault extends for about $35 \mathrm{~km}$ southeastwards as a blind thrust and is expressed in the shallow subsurface as a fault-related fold. No clear evidence was obtained, however, for its extension towards the northwest except for indi- 
Table I. Main parameters for the seismic reflection survey of the Fukaya Fault System.

\begin{tabular}{lc}
\hline \hline Seismic Source & Impactor (JMI-200) \\
Shot point interval & $5 \mathrm{~m}$ \\
Standard times of shot & \\
at each shot point & 10 \\
Receiver & 6-geophone array \\
Natural frequency & $30 \mathrm{~Hz}$ \\
Receiving point interval & $5 \mathrm{~m}$ \\
Standard receiving channels & 120 \\
Spread & End-on \\
Maximum offest & $600 \mathrm{~m}$ \\
Standard CMP fold & 60 \\
CMP interval & $2.5 \mathrm{~m}$ \\
Recording system & G.DAPS-4 \\
Record lenght & $2 \mathrm{~s}$ \\
Sampling interval & $1 \mathrm{~ms}$ \\
\hline
\end{tabular}

rect geomorphic evidence such as lineaments along the mountain foots.

We conducted high-resolution $P$-wave seismic reflection surveys in the suburbs of Takasaki (fig. 2) to confirm whether the Fukaya Fault extended to the northwest. We acquired $P$ wave seismic profiles on 3 lines shown in fig. 2: Kaburagawa line (1700 m long), Negoya line (800 m long), and Satomi line (2150 m long). An oil hydraulic impactor was used as a seismic source, and both the shot points and receiving points were set at $5 \mathrm{~m}$ intervals for all the three lines. Main parameters for the seismic reflection survey are shown in table I.

Figures 3, 4 and 5 show depth-converted seismic reflection profiles of each survey line. A flexure or fault-related fold is clearly imaged on each profile. A concealed flexure in the Kaburagawa profile illustrates detailed stratigraphic

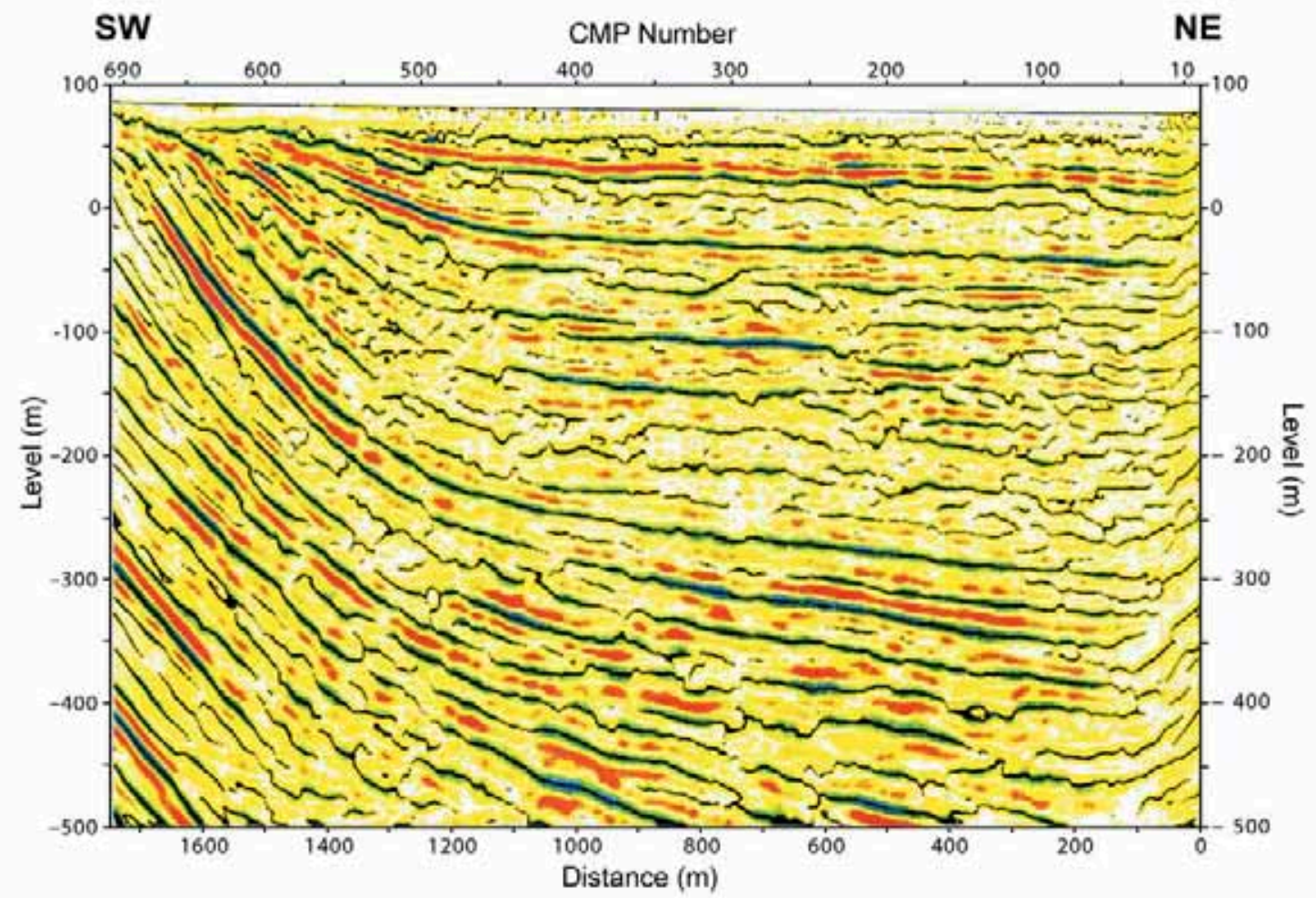

Fig. 3. Depth-converted seismic reflection profile for the Kaburagawa line to the south of Takasaki (vertical exaggeration $\times 2$ ). See fig. 2 for the location of the survey line. 


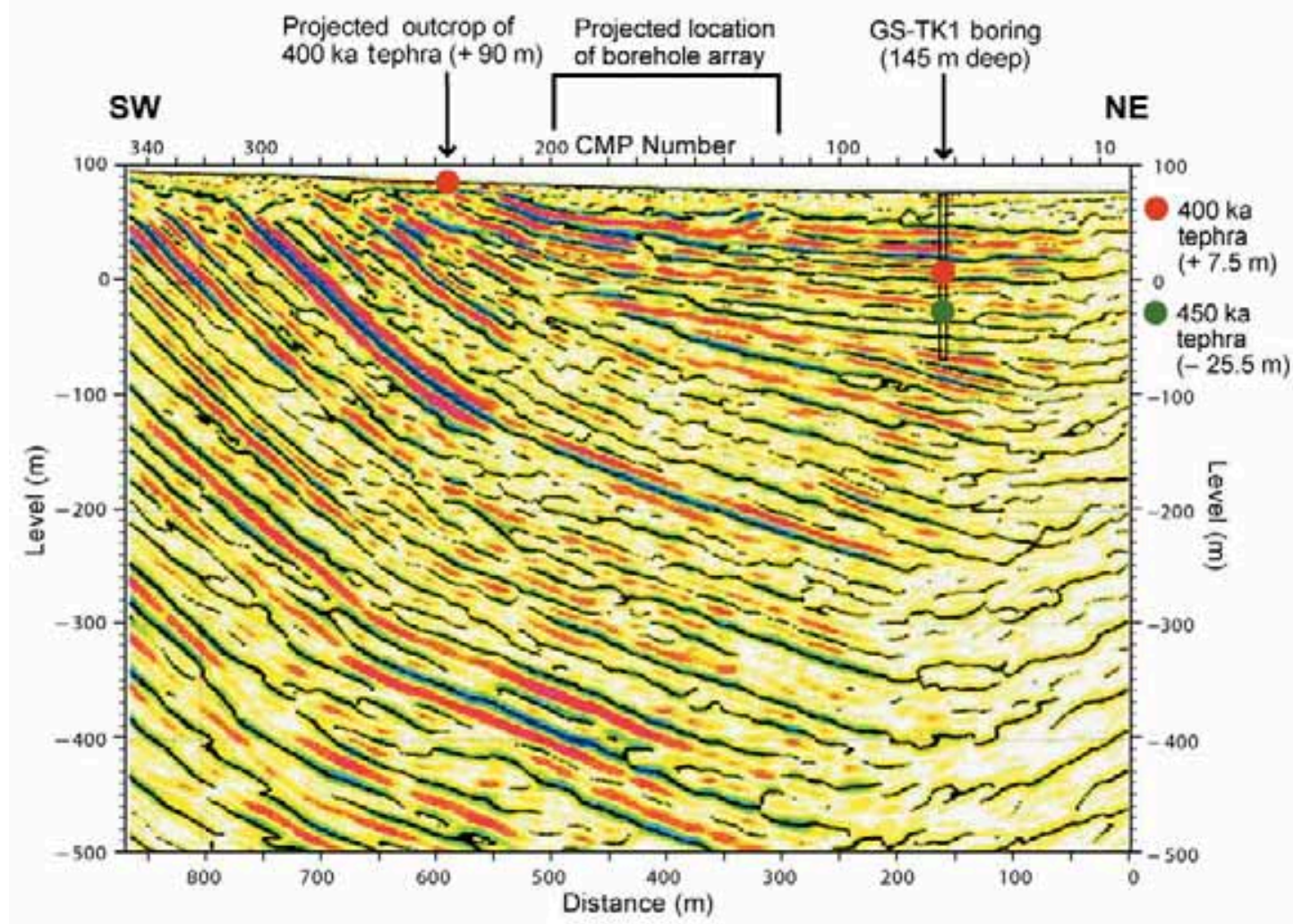

Fig. 4. Depth-converted seismic reflection profile for the Negoya line in Takasaki city (no vertical exaggeration). Both the location of borehole array and tephras recognized by $145 \mathrm{~m}$ deep boring and field survey are also projected. See fig. 2 for the location of the survey line.

growth architecture and cumulative deformation of the reflectors (fig. 3). The Negoya profile (fig. 4) is characterized by a kink fold with a hinge line dipping 50 to 60 degrees to the southwest. An angular unconformity is also clearly imaged in shallow strata (around 30 to $50 \mathrm{~m}$ below sea level) in the northeastern half of the profile. Although the Satomi profile (fig. 5) is rather low in resolution due to high traffic noise level in the study area, it extends across the entire monocline, which is around $600 \mathrm{~m}$ in width.

These results show that the Fukaya Fault extends for about $80 \mathrm{~km}$ in an $\mathrm{N} 60^{\circ} \mathrm{W}$ direction, and forms a fault system, the Fukaya Fault System, which is composed of several left-stepping en échelon faults.

\subsection{Continuously cored boring}

\subsection{1. $145 \mathrm{~m}$ long boring}

We collected a $145 \mathrm{~m}$ long core (GS-TK1) from the downthrown side of the Fukaya Fault System in the Takasaki area. The borehole was located close to the CMP (Common Mid Point) number 65 of the Negoya seismic line (fig. 4). We identified two tephras named TE 5 (ca. $400 \mathrm{ka}$ ) and Ks 5 (ca. $450 \mathrm{ka}$ ), which are widespread in Central and Western Japan, at a depth of $70 \mathrm{~m}(+7.5 \mathrm{~m}$ in altitude $)$ and $103 \mathrm{~m}$ ( $-25.5 \mathrm{~m}$ in altitude), respectively (Sugai et al., 2000). The TE 5 tephra also crops out on the hillside at about 90 to $96 \mathrm{~m}$ 


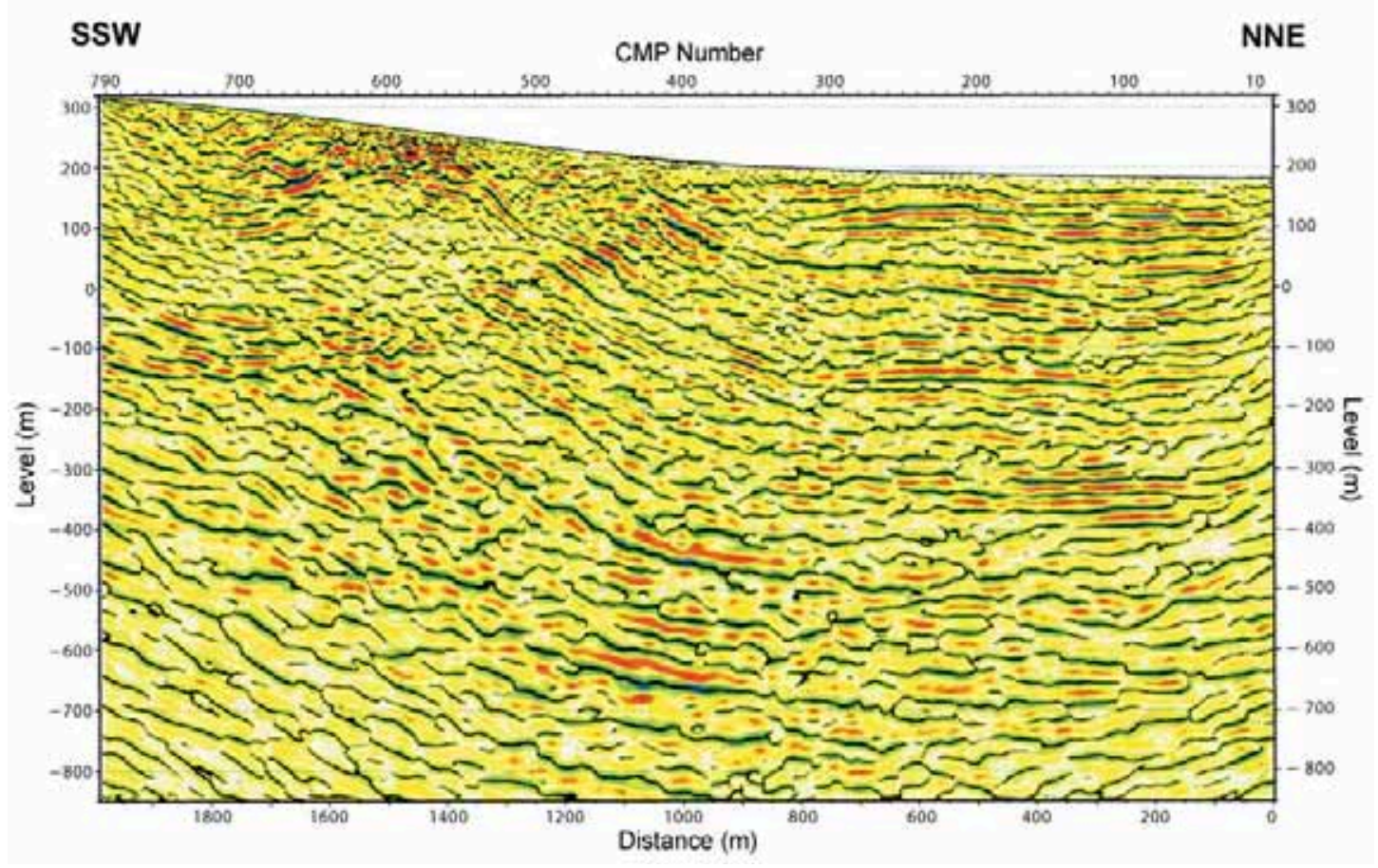

Fig. 5. Depth-converted seismic reflection profile for the Satomi line west of Takasaki (no vertical exaggeration). See fig. 2 for the location of the survey line.

in elevation on the upthrown side of the fault. On the Negoya profile, the exposure of the TE 5 tephra is projected just on the southwestward extension of the stratigraphic horizon where this tephra was found in the GS-TK1 core (fig. 4).

Based on the age of the TE 5 tephra and its measured vertical offset across the flexure, the long-term uplift rate of the Fukaya fault system in the Takasaki area is estimated to be more than $0.2 \mathrm{~m} / \mathrm{ky}$.

\subsubsection{Boring array}

We acquired an array of continuously cored boreholes to define the recency of displacement on the Fukaya Fault System. The 200 $\mathrm{m}$ long boring array was projected onto the flexure between CMP number 120 and 200 of the Negoya seismic profile (fig. 4). Figure 6 illustrates Late Quaternary strata defined by the boring array, which is composed of 13 (A$1 \sim \mathrm{A}-13$ ) cores ranging in length from 12 to $24 \mathrm{~m}$. Both volcanic mudflow deposits (stratigraphic unit E in fig. 6) of around $50 \mathrm{ka}$ and conformably overlying silt-rich formation (unit D) are deformed by the flexure. Vertical displacement of the unit E/D boundary is estimated at more than $10 \mathrm{~m}$. This value is consistent with the long-term uplift rate $(>0.2$ $\mathrm{m} / \mathrm{ky}$ ) across the Fukaya Fault System in the Takasaki area. The Holocene terrace deposits (units $\mathrm{C}$ and $\mathrm{B}$ ) that unconformably overlie the units $\mathrm{E}$ and $\mathrm{D}$, however, do not show evidence of deformation.

From these data, we conclude that the Fukaya Fault System in the Takasaki area was reactivated in the past $50 \mathrm{ky}$, although it remains uncertain whether the last faulting event occurred in Holocene time. 


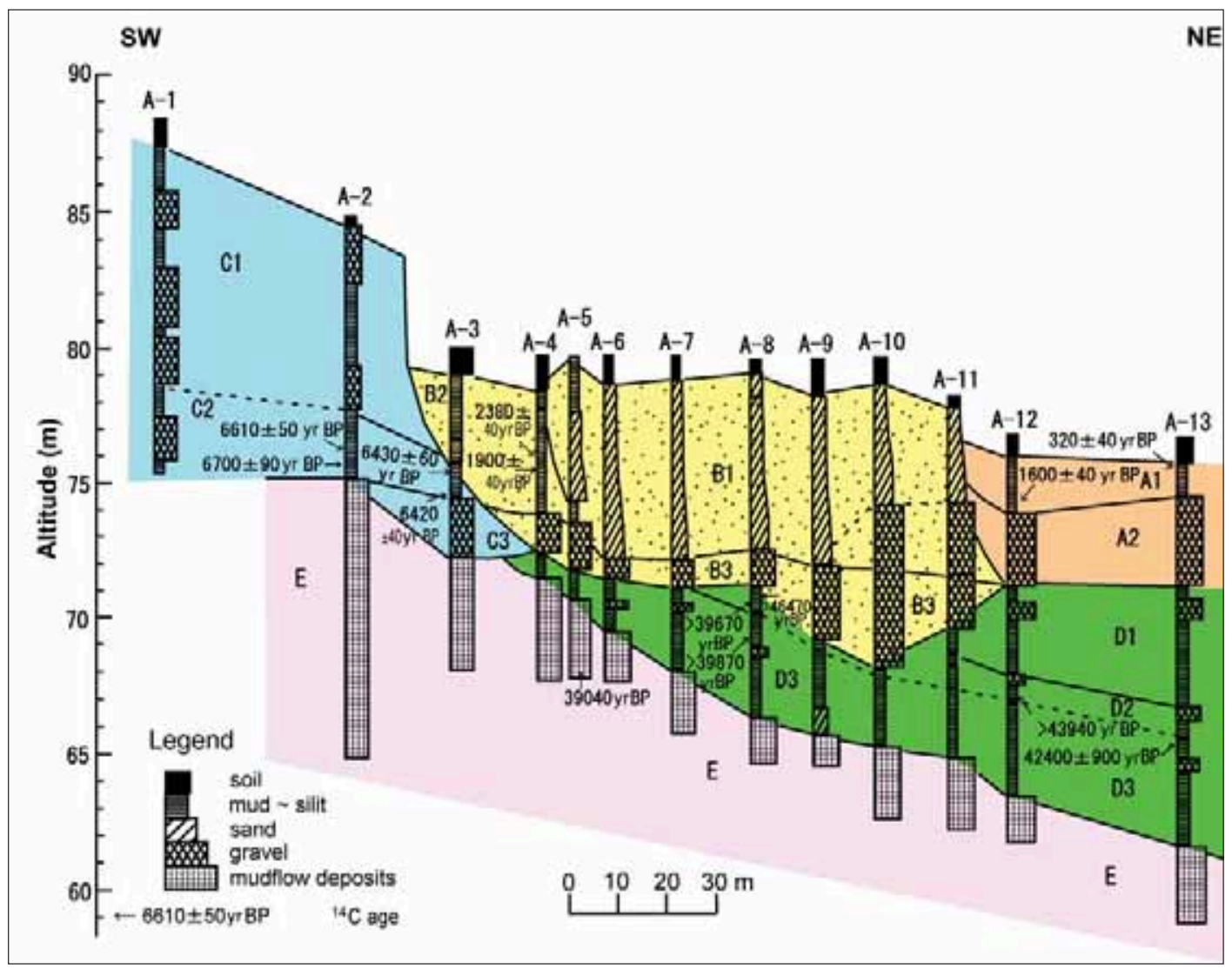

Fig. 6. Correlation of continuously cored boreholes within the flexure zone of the Fukaya Fault System in the Takasaki area. See fig. 4 for the projected location of the survey area. 5 stratigraphic units A-E are recognized, and each unit except for the unit $\mathrm{E}$ is divided into several subunits. After Mizuno et al. (2001).

\section{Uemachi Fault System in the Osaka Basin}

\subsection{Osaka Basin}

The Osaka Basin is situated in the easternmost part of the Seto Inland Sea immediate north of the E-W-striking Median Tectonic Line (MTL), which is here an active right-lateral fault system (figs. 1 and 7). The central and western parts of the basin are occupied by Osaka Bay (fig. 7). The northwestern margin of Osaka Bay is bounded by active faults extending from Awaji Island to the foot of the Rokko Mountains on the island of Honshu. The 1995 Kobe earthquake with over
6000 fatalities occurred on NE-striking faults in this region. The eastern onshore region of the basin is divided into the Kawachi Plain and coastal lowland by the N-S-trending Uemachi Fault System and adjoining Pleistocene Uemachi terrace. The Osaka metropolitan area with a population of more than 10 million is contained in the Eastern Osaka Basin. The basin is infilled with over $1000 \mathrm{~m}$ of Plio-Pleistocene deposits. Earthquake focal mechanisms, the strike of compressive folds and results of geodetic surveys indicate that the Osaka Basin is being actively shortened in an E-W to WNW-ESE direction. 


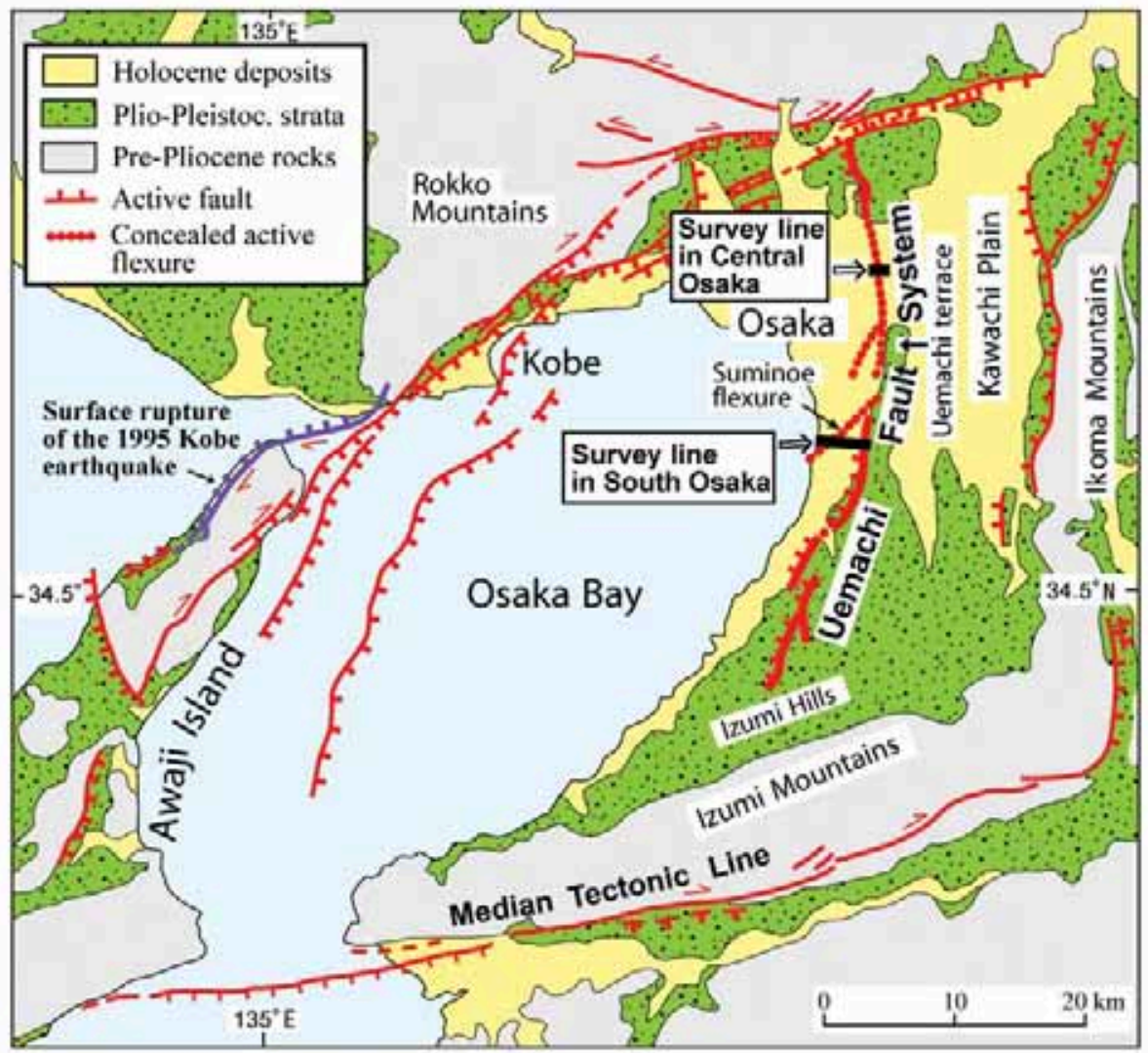

Fig. 7. Simplified geologic map of the Osaka Basin. The basin is bounded by Awaji Island on the west and the Rokko Mountains on the north. It is also bounded on the south by the Izumi Mountains along the Median Tectonic Line and by the Ikoma Mountains on the east.

\subsection{Uemachi Fault System}

Recent acquisition of seismic reflection profiles (e.g., Osaka City, 1996; Sugiyama, 1997) and mapping of deformed terrace deposits with air photos (e.g., Nakata et al., 1996; Okada et al., 1996) suggest that the Uemachi Fault System extends for about $45 \mathrm{~km}$, and branches repeatedly towards the south (fig. 7). Along the southern part of the Uemachi Fault System, fluvial terraces of the Last Glacial Stage are vertically offset about $6 \mathrm{~m}$ in a fault-related fold formed above blind thrusts of the fault system. Based on borehole data, the long-term uplift rate since the Middle Pleistocene is estimated to be 0.3-0.4 $\mathrm{m} / \mathrm{ky}$ for the central part of the fault system (e.g., Osaka Prefecture, 1999). The cumulative vertical displacement of pre-Neogene basement rocks by the Uemachi Fault System is more than $500 \mathrm{~m}$.

\subsection{Combination survey of high-resolution S- wave reflection profiling and continuous coring for the Uemachi Fault in Central Osaka}

We conducted a combination survey of highresolution $S$-wave reflection profiling and continuous coring across the Uemachi Fault in Central Osaka to constrain the rate and recency of move- 
Table II. Main parameters for the seismic reflection surveys of the Uemachi Fault System.

\begin{tabular}{llll}
\hline \hline Survey area & Central Osaka & South Osaka & South Osaka \\
Survey line length & $790 \mathrm{~m}$ & $4300 \mathrm{~m}$ & $310 \mathrm{~m}$ \\
Applied seismic wave & -wave & $P$-wave & $S$-wave \\
Seismic source & Plate hitter & Mini vibrator & Plate hitter \\
Shot point interval & $1 \mathrm{~m}$ & $10 \mathrm{~m}$ & $1 \mathrm{~m}$ \\
Standard times of shot at each shot point & $15 \sim 20$ & $10 \sim 15$ & $40 \sim 60$ \\
Receiver & 3 -geophone array & 9 -geophone array & 3 -geophone array \\
Natural frequency & $30 \mathrm{~Hz}$ & $27 \mathrm{~Hz}$ & $30 \mathrm{~Hz}$ \\
Receiving point interval & $1 \mathrm{~m}$ & $10 \mathrm{~m}$ & $1 \mathrm{~m}$ \\
Standard receiving channels & 120 & 70 & 100 \\
Spread & End-on & Off-end & End-on \\
Maximum offset & $120 \mathrm{~m}$ & $730 \mathrm{~m}$ & $100 \mathrm{~m}$ \\
Standard CMP fold & 60 & 35 & 50 \\
CMP interval & $0.5 \mathrm{~m}$ & $5 \mathrm{~m}$ & $0.5 \mathrm{~m}$ \\
Recording system & G·DAPS-4 & Strata view 60 & G.DAPS-4 \\
Record length & $2 \mathrm{~s}$ & $2 \mathrm{~s}$ & $1.5 \mathrm{~s}$ \\
Sampling interval & $1 \mathrm{~ms}$ & $1 \mathrm{~ms}$ & $1 \mathrm{~ms}$ \\
\hline
\end{tabular}

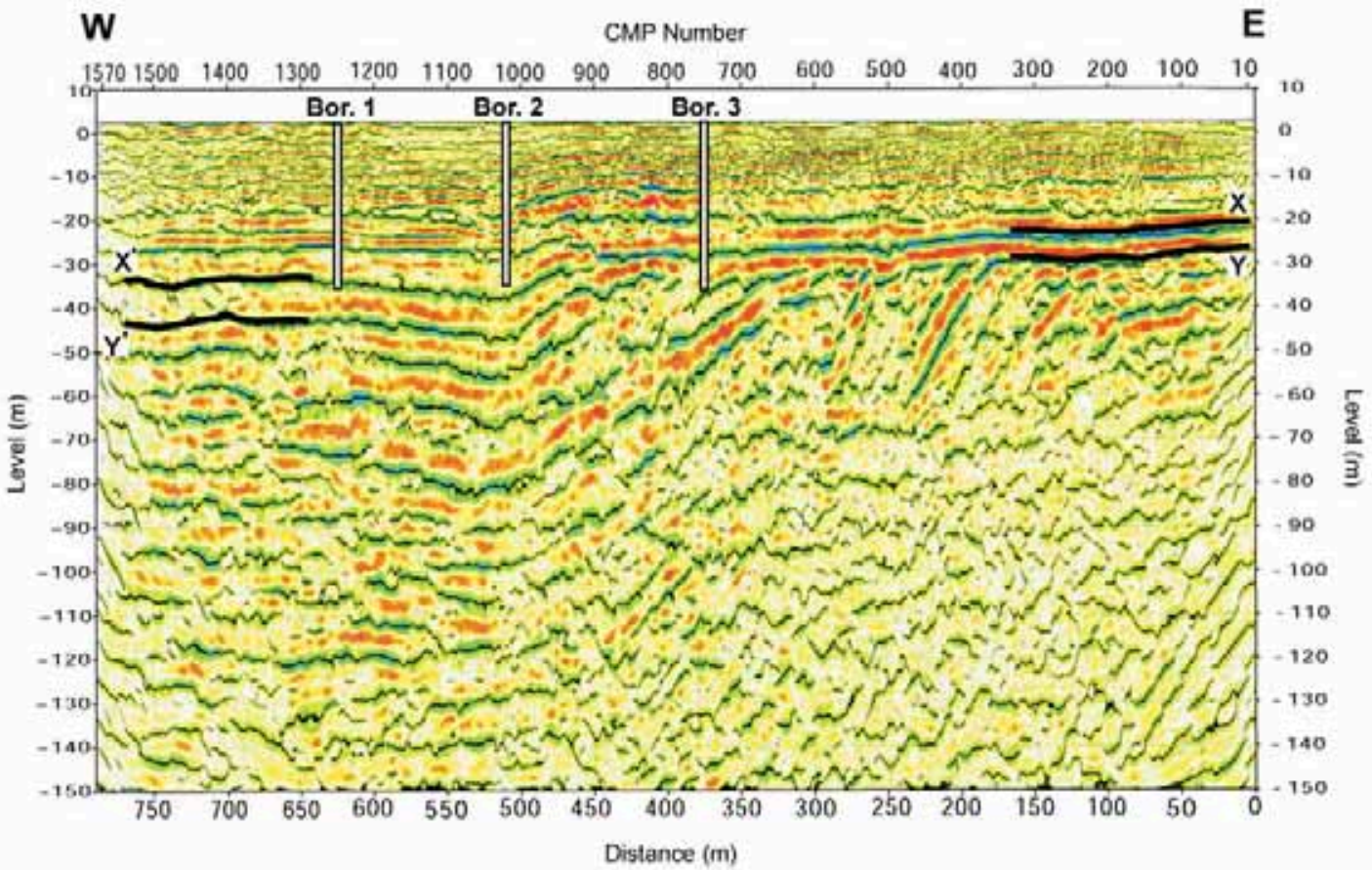

Fig. 8. Depth-converted $S$-wave reflection profile of the Uemachi Fault in Central Osaka (vertical exaggeration $\times 3$ ). See fig. 7 for the location of the survey line. Reflection surfaces $X$ and $X^{\prime}$ are correlative to the base of the Holocene Nanba Formation on the upthrown and downthrown sides of the fault, respectively. Reflection surface $Y$ is probably correlated to the base of the Tenma Formation on the upthrown side, and $Y^{\prime}$ is supposed to be the equivalent horizon on the downthrown side. Locations of three continuously cored boreholes are also shown on the profile. 
ment along it in Holocene time. A 790 m long survey line was located along the north bank of the Shin-Yodo River, where the Uemachi Fault had been previously identified by a $P$-wave seismic reflection profile (Yamamoto et al., 1992). Acqui- sition and processing parameters for the $S$-wave reflection survey are shown in table II.

The Uemachi Fault is clearly imaged as a flexure, or fault-related fault (fig. 8). A sharp angular unconformity shown by reflection surface $Y$ was

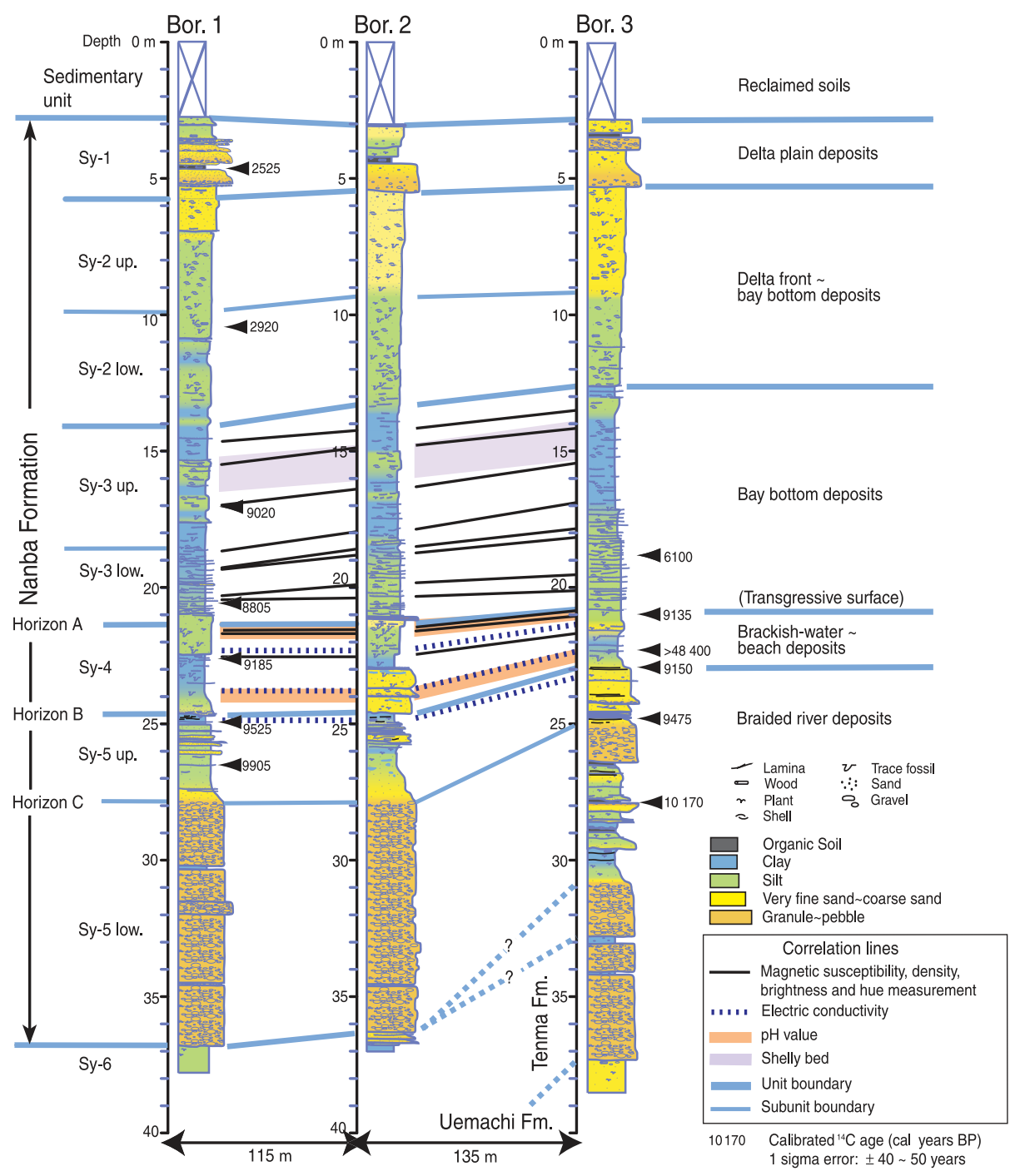

Fig. 9. Summarized stratigraphic correlation between boreholes 1,2 and 3. The elevation of the three borehole sites is $2.5 \mathrm{~m}$ above the sea level. See fig. 8 for the location of each boring site. A clay bed intercalated at the depth of $33 \mathrm{~m}$ of borehole 3 is correlated to the Tenma Formation because it yields a pollen assemblage of the first half of the Last Glacial Stage. After Miura et al. (2002). 
imaged in the eastern (right) part of the profile. Based on boring data, this unconformity is correlated with the boundary between the Uemachi Formation of the Last Interglacial Stage and the overlying Tenma Formation dated as $\mathrm{ca}$. 50 to $25 \mathrm{ka}$. Although the flexure deformation is interpreted to reach the lower part of Holocene deposits (Nanba Formation), it is difficult to constrain the timing of the last faulting event only by the seismic reflection results.

We therefore acquired three continuous cores, all about $40 \mathrm{~m}$ long, from the downthrown side, the flexure foot, and the upthrown side (fig. 8). More than 15 correlative horizons were recognized in these cores by detailed analysis of sedimentary facies, pollen and volcanic ash as well as measurement of physical properties such as electric conductivity, $p H$, and magnetic susceptibility.

Correlation of shallow deposits (fig. 9) shows that the vertical separation of correlative horizons in the stratigraphic unit Sy-3 between boreholes 1 and 2 is nearly the same as that between boreholes 2 and 3 across the flexure. This result suggests that the difference in height between these correlative horizons in the three boreholes is of sedimentary origin, and that unit Sy-3 is not deformed by the flexure. Correlative horizons in units Sy-4 and Sy-5 were identified at nearly the same level between boreholes 1 and 2, while they show gradual upward decrease in height difference between boreholes 2 and 3 across the flexure. This gradual upward decrease in height difference across the flexure implies burial of a flexure scarp formed by a faulting event. Therefore we can point out a possibility that the latest faulting event occurred either around horizon $\mathrm{C}$, or during the deposition of the under lying lower part of subunit Sy-5, although the ex act stratigraphic horizon of the latest event is not known because of the lack of correlative horizons within this subunit.

Based on the above seismic and boring survey results, we conclude that the most recent displacement of the blind Uemachi Fault occurred between about $9.5 \mathrm{ka}$ and $25 \mathrm{ka}$, after deposition of the Tenma Formation, and before deposition of the stratigraphic unit Sy-4. The vertical surface displacement associated with the last faulting event might attain $3 \mathrm{~m}$, assuming that the height diffe-

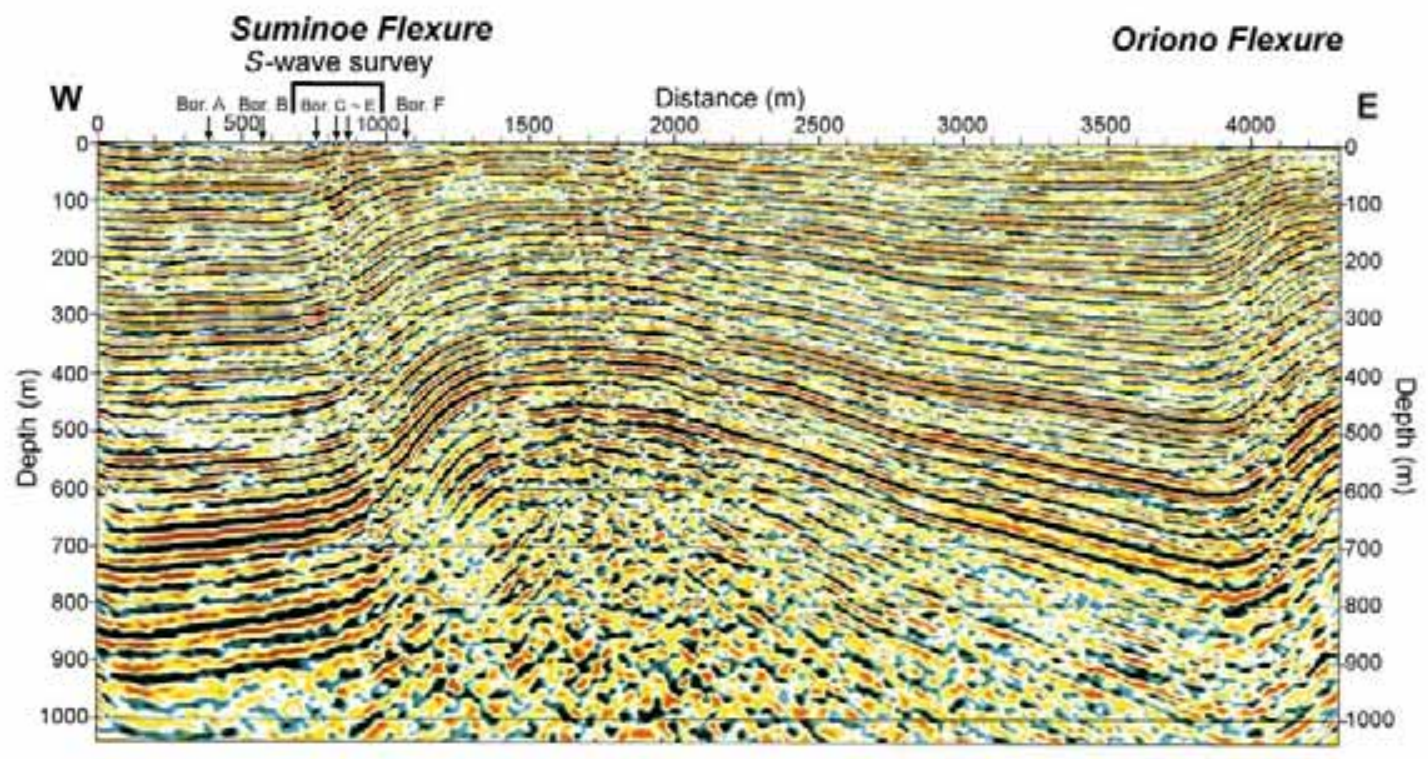

Fig. 10. Depth-converted $P$-wave seismic reflection profile across the Suminoe and Oriono flexures in south Osaka (vertical exaggeration $\times 2$ ). See fig. 7 for the location of the survey line. Locations of $S$-wave reflection survey line and six boring sites are also shown on the profile. 
rence of horizon $\mathrm{C}$ between boreholes 2 and 3 directly reflects the flexure deformation during the last faulting event. From the minimum elapsed time of $9.5 \mathrm{ky}$ since the last faulting event and long-term uplift rate of $0.3-0.4 \mathrm{~m} / \mathrm{ky}$, about $3 \mathrm{~m}$ or more vertical surface displacement is expected for the next faulting event. This value is comparable to the above-discussed vertical displacement during the last event.
3.4. Combination survey of high-resolution seismic reflection profiling and continuously cored borehole array for the Suminoe flexure in South Osaka

We also studied the Suminoe flexure, a major component of the southern part of the Uemachi Fault System, using a combination of seismic reflection profiling (table II) and an array of con-

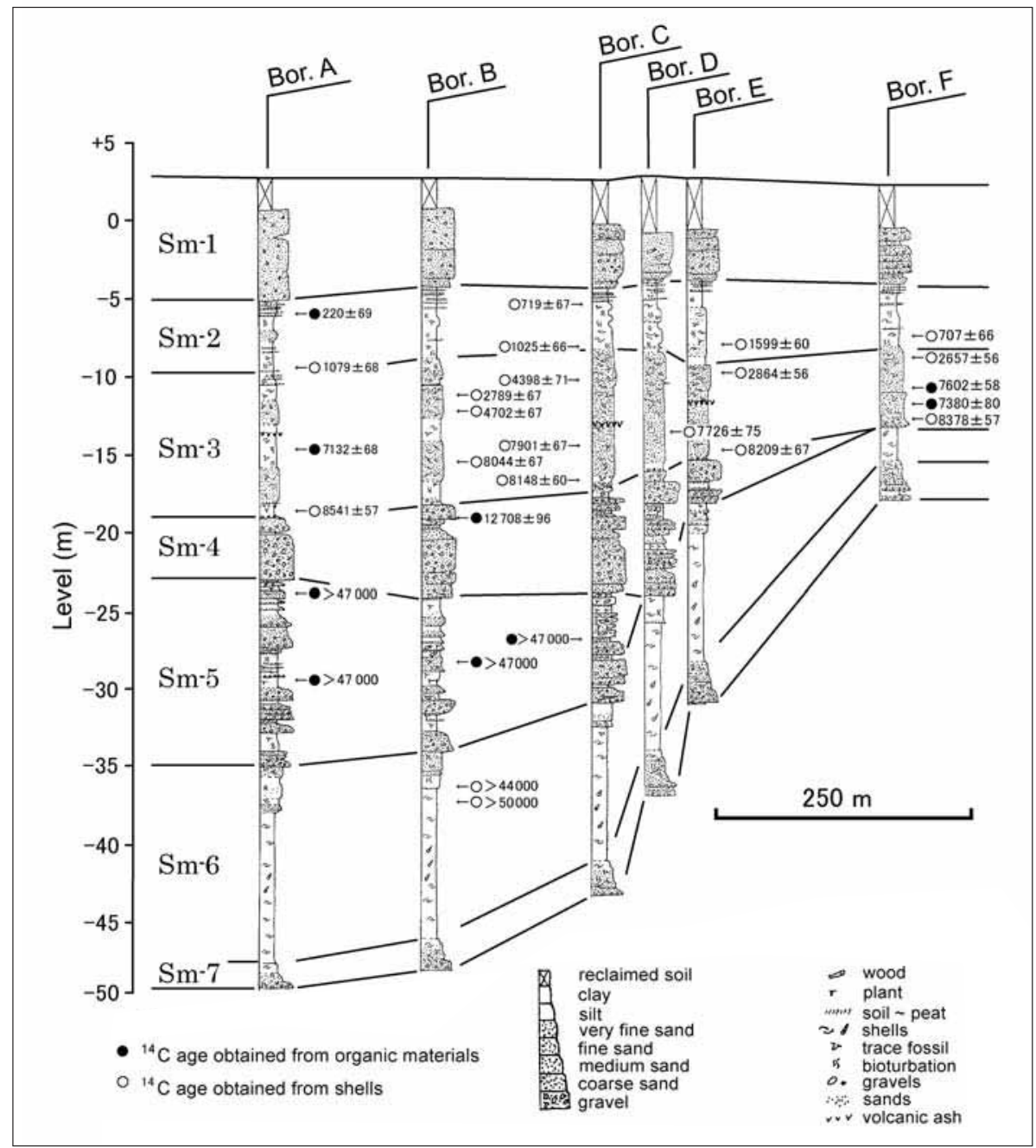

Fig. 11. Correlation of continuously cored boreholes across the Suminoe flexure in South Osaka. See fig. 10 for the location of each boring site. Modified from Nanayama et al. (2000a). 


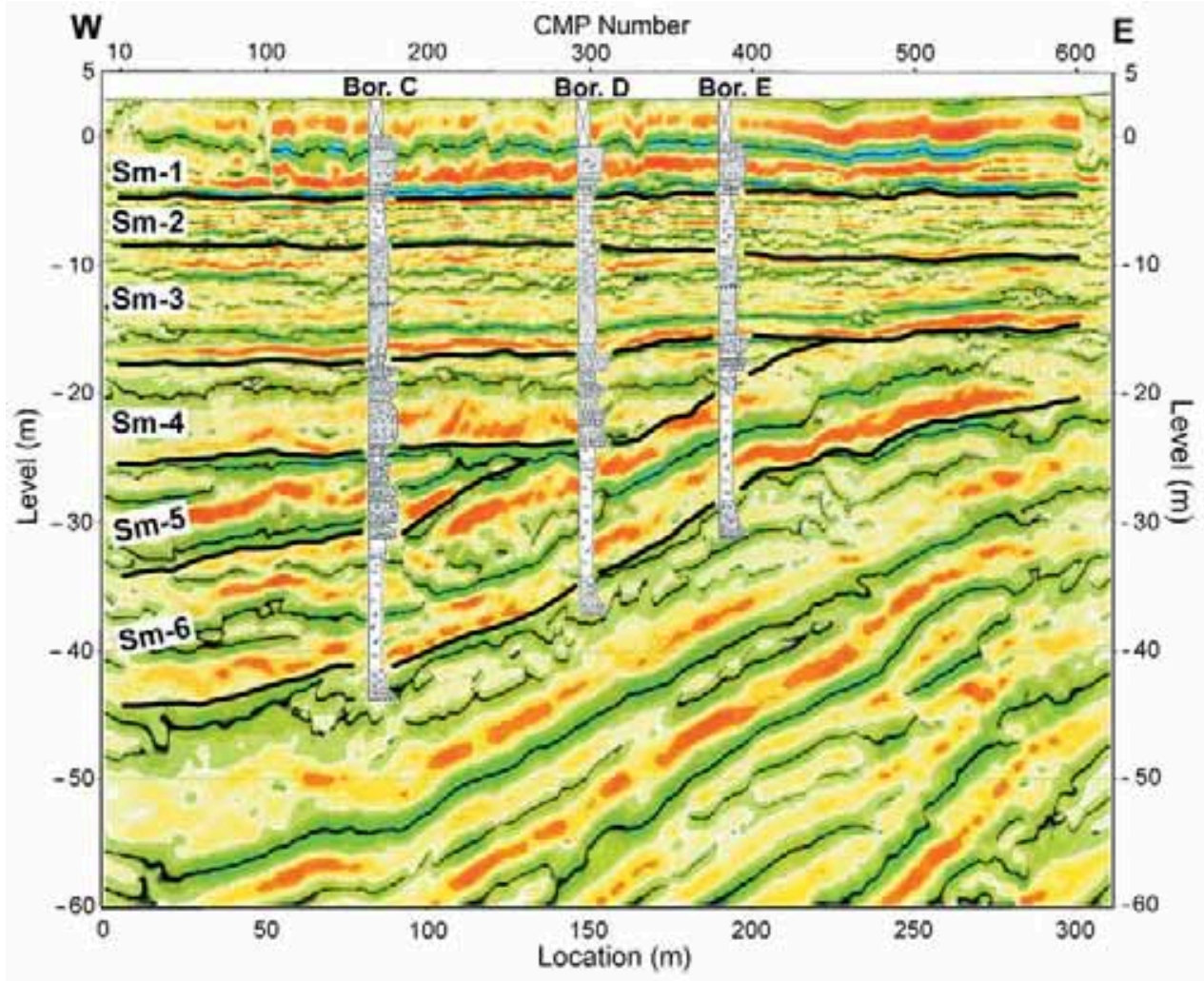

Fig. 12. Depth-converted $S$-wave seismic reflection profile across the Suminoe flexure combined with the boring survey result (vertical exaggeration $\times 4$ ). See fig. 10 for the location of the survey line.

tinuously cored boreholes. We first acquired a $4300 \mathrm{~m}$ long $P$-wave seismic reflection profile (fig. 10) across both the locally named Oriono flexure along the western hillside of the Uemachi terrace and the Suminoe flexure, which is completely concealed beneath Holocene deposits in the coastal plain. The profile clearly imaged both the Oriono and Suminoe flexures as typical fault-propagation folds with compressive growth architecture (e.g., Suppe et al., 1992; Allmendinger, 1998). On the basis of the seismic profile and existing borehole data, the long-term uplift rates of the Oriono and Suminoe flexures were estimated to be $0.25 \mathrm{~m} / \mathrm{ky}$ and $0.15 \mathrm{~m} / \mathrm{ky}$, respectively. In addition, Holocene deposits around the Suminoe flexure were inferred to be more than $15 \mathrm{~m}$ in thickness from existing bore- hole data. Consequently we chose the Suminoe flexure as the target fault for clarifying the recent activity by high-resolution $S$-wave seismic reflection profiling coupled with an array of continuously cored boreholes.

We acquired a $310 \mathrm{~m}$ long $S$-wave reflection profile across the Suminoe flexure and obtained six continuous cores ranging in length from 21 to $55 \mathrm{~m}$. Correlation of Late Quaternary deposits among the six cores (fig. 11) is quite consistent with the $P$-wave and $S$-wave reflection profiles. The $S$-wave profile, coupled with the stratigraphy defined in the cores (fig. 12), shows that the stratigraphic unit $\mathrm{Sm}-4$ unconformably overlies the tilted unit $\mathrm{Sm}-5$, and onlaps the flexure scarp made up of the older unit $\mathrm{Sm}-6$. It is also clearly shown that unit $\mathrm{Sm}-4$ 
and overlying units are not involved in the deformation.

Based on our interpretation of the $S$-wave profile linked with the borehole array, we conclude that the most recent activity of the Suminoe flexure occurred after deposition of unit $\mathrm{Sm}-5$ whose age is estimated at 70-50 ka based on its pollen assemblage (Nanayama et al., 2001a), and before deposition of unit Sm-4 dated as 15-10 ka. Nanayama et al. (2001b) estimated an average uplift rate of $0.2 \mathrm{~m} / \mathrm{ky}$ for the last $130 \mathrm{ky}$ based on the assumption that the original depositional dip of the base of unit $\mathrm{Sm}-7$ is the same as that of the base of unit Sm-3. This uplift rate, together with the minimum elapsed time of $15 \mathrm{ky}$ since the last faulting event, implies that $3 \mathrm{~m}$ of vertical displacement has been stored on the Suminoe flexure.

\section{Concluding remarks - problems and future research}

Our work in the Kanto and Osaka basins has demonstrated the effectiveness of combining acquisition and analysis of high-resolution seismic profiles and continuously cored boreholes to assess the paleoseismic record of blind thrusts underlying densely populated and urbanized areas. It is, however, still difficult to constrain the exact timing of the most recent faulting event on blind thrusts because they are expressed at the surface as a wide deformation zone of flexure. This mainly stems from a difficulty in detecting differences between deformed layers and nondeformed beds, or differences between subtle tectonic tilting and primary depositional dip. Use of a newly developed device termed a Geoslicer (Nakata and Shimazaki, 1997; Atwater et al., 2001) may improve paleoseismic records on blind thrusts by defining and dating liquefaction or subaqueous slides produced by paleoearthquakes.

We have focused on the slip rate as a target fault parameter in our blind fault study. It provides a basis for estimating moment release rates and constraining future earthquakes on blind faults (e.g., Oskin et al., 2000). It also can be coupled with structural models of fault-related fold growth (e.g., Schneider et al., 1996;
Cannon et al., 2001). Our estimates of slip rates for the Fukaya and Uemachi fault systems, however, are based only upon data obtained from the subsurface several tens to several hundreds meters deep. The slip rates in such a shallow part might be smaller than those at depths where seismic energy is substantially released (e.g., Stein and King, 1984). The effect of compaction on thickness of deposits also must be taken into consideration for estimating slip rates (e.g., Schneider et al., 1996). We need to make further efforts to clarify the slip rate of the deeper part of these fault systems for acquiring more plausible earthquake scenarios for Tokyo and Osaka.

\section{Acknowledgments}

We thank Robert S. Yeats and Karl Mueller for their helpful and constructive comments by which this paper was significantly improved.

\section{REFERENCES}

ABE, K. (1974): Seismic displacement and ground motion near a fault: the Saitama earthquake of September 21, 1931, J. Geophys. Res., 79, 4393-4399.

ALLMENDINGER, R.W. (1998): Inverse and forward numerical modeling of trishear fault-propagation folds, Tectonics, 17, 640-656.

Atwater, B., D. Baker, W. Barnhardt, K. Burrell, T. HaraGUChi, B. Higman, R. KAYEN, D. Minasian, T. NaKata, K. Satake, K. Shimokawa, K. TaKada and M. CisterNAS V. (2001): Grouted sediment slices show signs of earthquake shaking, Eos, 82, 603-608.

Cannon, E., K. Mueller, Y. SugiYama and N. Kitada (2001): Coseismic growth of active fault-propagation folds by heterogeneous shear, Kansai Region, Japan, in Abstracts for the AGU 2001 Fall Meeting (Supplement to Eos, 82, n. 47), F1230.

GEOGRAPHICAL SURVEy InSTITUTE (2002): Information on Crustal Deformation in the Recent 10 and 100 Years, available from http://cais.gsi.go.jp/HIZUMI/hizumi.html (in Japanese).

Ikawa, T, T. KaWanaKa, T. Kozawa, T. ITOH, K. Kasahara and H. SATO (1998): Subsurface structure derived from the seismic reflection survey at northwestern part of Kanto Plain, in Abstracts for the 1998 Japan Earth and Planetary Science Joint Meeting, SL-p013 (in Japanese).

InAZAKI, T., S. Jimbo, M. NAGASAWA, M. AbE, K. IkedA and Y. Sugimoto (1988): Seismic reflection in the West Kumagaya, Saitama Prefecture, in Proceedings of the 78th Society of Exploration Geophysicists of Japan Conference, 110-113 (in Japanese with English abstract, table and figures) 
KASAHARA, K. (1996): Vibroseis reflection survey, in Report on Comprehensive Research on Enhancing Forecast Techniques for Earthquakes directly under the Tokyo Metropolitan Area (2nd stage), Science and Technology Agency, 66-78 (in Japanese).

KASAHARA, K., F. YAMAMIZU, T. IKAWA and I. AdACHI (1993): Seismic reflection profiles across the Kanto Plain, in $A b$ stracts for the 1993 Fall Meeting of the Seismological Society of Japan, 262 (C86) (in Japanese).

Miura, K., F. Nanayama, M. Uchiumi, Y. Sugiyama, M. YASUHARA, Y. YoKOYAMA, N. KITADA and K. TAKEMURA (2002): Holocene activity of the Uemachi Fault in the Osaka Plain evaluated by high-resolution analysis of the Shin-Yodo-gawa array boring cores, Annual Report on Active Fault and Paleoearthquake Researches, 2, 109-123, Geological Survey of Japan (in Japanese with English abstract and figure captions).

Mizuno, K., T. SugaI, Y. SugiYama, T. Hosoya, H. KuRosawa and H. Yoshida (2001): Late Pleistocene to Holocene activity of the Fukaya Fault System in Gunma Prefecture, Tokyo megalopolis, revealed by arrayed boring, Аnnual Report on Active Fault and Paleoearthquake Researches, 1, 77-86, Geological Survey of Japan (in Japanese with English abstract and figures).

NAKATA, T. and K. ShimaZAKI (1997): Geo-slicer, a newly invented soil sample, for high-resolution active fault studies, J. Geogr., 106, 59-69 (in Japanese with English abstract and captions for figures and photos).

NAKata, T., A. OKadA, Y. SuZuKi, M. Watanabe And Y. IKedA (1996): Osaka Seinanbu, Active Fault Map in Urban Area, scale 1:25000, Geographical Survey Institute (in Japanese)

NANAYAmA, F., Y. DoI, N. KitadA and K. TAKEMURA (2001a): Stratigraphic, sequence stratigraphic and sedimentary environment analyses on the Late Pleistocene-Holocene sediments of the eastern side of Osaka Bay, Central Japan since 130 ka, J. Geol. Soc. Japan, 107, 179-197 (in Japanese with an English abstract).

Nanayama, F., Y. Doi, N. Kitada, K. Takemura and Y. SugiYama (2001b): Activity study of the Suminoe flexure, a branch of the Uemachi Fault System and estimated sea level change during the past 10000 years, in the Western Osaka Plain, Central Japan, J. Geol. Soc. Japan, 107, 215 221 (in Japanese with an English abstract).

OKadA, A., N. ChIDA and T. NAKATA (1996): Kishiwada, Active Fault Map in Urban Area, scale 1: 25000, Geographical Survey Institute (in Japanese).

OSAKA CITY (1996): Study of the Uemachi Fault, in Abstracts for the Conference on Nationally-Funded Active Fault Study in 1995 and 1996 Fiscal Years, Science and Technology Agency, 90-94 (in Japanese).

OSAKA PREFECTURE (1999): Report on the Study of the Uemach Fault Zone (excerpts), pp. 39 (in Japanese).

Oskin, M., K. Sieh, T. Rockwell, G. Miller, P. Guptill, M. CurTiS, S. MCARDLE and P. Elliot (2000): Active parasitic folds on the Elysian Park anticline: implications for seis- mic hazard in Central Los Angeles, California, GSA Bull., 112, 693-707.

Saitama Prefecture (1996): Report on the Study of the Ayasegawa Fault, pp. 200 (in Japanese).

SAITAMA PREFECTURE (1999): Report on the Study of the Fukaya Fault, pp. 83 (in Japanese).

Schneider, C.L., C. Hummon, R.S. Yeats and G.L. Huftile (1996): Structural evolution of the Northern Los Angeles basin, California, based on growth strata, Tectonics, 15, 341-355.

STEIN, R.S. and G.C.P. KING (1984): Seismic potential revealed by surface folding: 1983 Coalinga, California, earthquake, Science, 224, 869-872.

Sugai, T., K. Mizuno and Y. SugIYAma (2000): Long-term activity of the Fukaya Fault System at Takasaki, Gunma Prefecture, revealed by 145 m-deep core (GS-TK1) analysis, Interim Report on Active Fault and Paleoearthquake Researches in the 1999 Fiscal Year, Geological Survey of Japan, 61-76 (in Japanese with English abstract, tables and figures).

SugrYAMA, Y. (1997): Seismic reflection survey of the Uemachi Fault System, Geological Survey of Japan Open-file Report, 303, 105-113 (in Japanese with English figures).

Sugiyama, Y., T. Sugai, R. Imura, K. Mizuno, H. Endo, K. SHIMOKAWA and H. YAMAZAKI (1997): Neotectonic Map Tokyo (2nd edition), scale 1: 500000, Geological Survey of Japan (in Japanese with an English abstract).

Suppe, J., G.T. CHOU and S.C. HoOK (1992): Rates of folding and faulting determined from growth strata, in Thrust Tectonics, edited by K.R. MCCLAY (Chapman \& Hall, London), 105-121.

Yamaguchi, K., N. Kano, T. Yokota, T. Yokokura and T. KIGUCHI (1996): Seismic reflection survey in Kushibiki area, Saitama Prefecture, Central Japan, Zisin (2nd ser.), 49, 327-335 (in Japanese with English abstract, table and figures).

Yamaguchi, K., T. YoKoKuRA, N. Kano, T. Kiguchi, Y. NaKashima, T. OhtaKi and H. Sato (1998): Seismic reflection survey near the Yoshimi hill, Saitama Prefecture in Abstracts for the 1998 Fall Meeting of the Seismological Society of Japan, A49 (in Japanese).

Yamaguchi, K., N. Kano, T. Yokokura, T. Kiguchi, T. Yokota, A. TANAKA and H. SATO (2000): Seismic reflection survey around the Fukaya fault - subsurface structure between the Konan terrace and the Menuma lowland-, Zisin (2nd ser.), 53, 115-125 (in Japanese with English abstract, tables and figures).

YAMAMOTO, E., K. NAKAGawa, M. Mitamura, S. TOda, T. NishidA, Y. TeradA, H. UdA and H. Yokota (1992): Seismic reflection method at the Central Osaka plain Yodo River (Juso Kunijima) line-, in Proceedings for the 1992 Meeting of the Japan Society of Engineering Geology, 185-188 (in Japanese).

YAMAZAKI, H. (1984): On the relationship between active faults and basin-forming movement, Geogr. Rept. Tokyo Metropolitan Univ., 19, 67-78. 
